\title{
PENGUKURAN SSIM DAN ANALISIS KINERJA METODE INTERPOLASI UNTUK PENINGKATAN KUALITAS CITRA DIGITAL
}

\author{
Meirista Wulandari ${ }^{1}$ \\ ${ }^{1}$ Jurusan Teknik Elektro, Universitas Tarumanagara Jakarta \\ meiristaw@ft.untar.ac.id
}

\begin{abstract}
ABSTRAK
Terdapat banyak aplikasi pengenalan pola yang membutuhkan input citra dengan ukuran tertentu. Ukuran dari citra mempengaruhi hasil dari pengenalan pola tersebut. Metode interpolasi seringkali digunakan untuk mengatur ukuran citra. Kualitas citra hasil interpolasi tergantung dari metode interpolasi yang diterapkan. Pengukuran kualitas citra hasil interpolasi dapat dilakukan dengan pendekatan kualitas indeks. Salah satu pendekatan indeks kualitas yang sering digunakan adalah SSIM. Selain kualitas citra, metode interpolasi juga berpengaruh terhadap perubahan tekstur citra. Tekstur citra adalah fitur utama yang sering digunakan pada pengolahan citra dan computer vision untuk mengklasifikasikan suatu objek. Salah satu metode untuk melihat karakteristik tekstur citra adalah dengan statistik citra tersebut. Metode statistik mengkarakteristikkan tekstur citra berdasarkan distribusi statistik citra. Penelitian ini membanding 4 metode interpolasi yaitu NNI, Bilinear Interpolation, Bicubic Interpolation dan NNV. Keempat metode interpolasi tersebut dianalisis dengan kuantitatif parameter dari tekstur citra. Parameter yang dimaksud adalah rerata, standar deviasi, skewness, energi, entropi dan kehalusan. Sepuluh buah citra uji digunakan pada penelitian ini. Berdasarkan keenam fitur yang dianalisis, nilai skewness suatu citra sangat terpengaruh proses interpolasi. Perubahan nilai skewness dari citra hasil interpolasi dengan citra asli mencapai $800 \%$, Perubahan energi mencapai 90\%, entropi 75\%, kehalusan 18\%, standar deviasi $10 \%$ dan rerata 0,9\%. Pengukuran SSIM dengan metode Bicubic Interpolation menghasilkan nilai SSIM yang lebih tinggi dibandingkan dengan metode lainnya.
\end{abstract}

Kata kunci: interpolasi, tekstur, kualitas, citra, SSIM

\section{PENDAHULUAN}

Teknik pengolahan citra sudah banyak berkembang dalam berbagai bidang, termasuk dalam bidang peningkatan gambar dengan resolusi rendah menjadi gambar dengan resolusi tinggi atau pun sebaliknya (Han, 2013) (Gonzales, 2002). Kualitas gambar hasil pengolahan tergantung dari teknik interpolasi yang digunakan. Selama beberapa tahun terakhir, berbagai teknik pengolahan citra telah dikembangkan seperti teknik kompresi, teknik restorasi, teknik filter dan segmentasi. Namun teknik interpolasi masih kurang dieksplorasi (Nagwanshi, 2012).

Penilaian kualitas citra dapat dibagi menjadi 2 cara yaitu secara subjektif dan secara objektif (Kreis, 2004) (Sayood, 2002). Penilaian secara subjektif adalah cara penilaian kualitas citra berdasarkan persepsi manusia (Farrel, 1999). Penilaian ini kurang efektif dan efisien serta memerlukan cukup banyak waktu, karena dibutuhkan waktu untuk mencarai para penilai dan waktu untuk menunggu nulai dari para penilai berdasarkan pendapat mereka masing-masing (Soong, 2012). Penilaian secara objektif adalah cara penilaian kualitas citra dengan memanfaatkan algoritma matematik berdasarkan suatu kriteria (Cadik, 2004) (Ziou, 2000).

Sistem Content Based Image Retrieval (CBIR) adalah suatu sistem yang mengaplikasikan penggunaan analisa citra untuk mengekstrak secara otomatis sejumlah atribut citra suatu waktu pada database citra (Hastuti, 2009). Dalam sistem CBIR (Hsu, 1992) (Jain, 2000), fitur adalah suatu karakteristik yang dapat menangkap informasi visual dari suatu citra baik secara global atau lokal. Tekstur adalah fitur utama yang digunakan dalam pengolahan citra dan computer vision untuk mengklasifikasikan suatu objek. Karena Citra digital tersusun dari sejumlah piksel, tekstur dapat didefinisikan sebagai kesatuan piksel-piksel yang saling berhubungan antara satu piksel dengan yang lainnya (Kodituwakku, 2011). Salah satu metode yang dapat menyatakan hubungan tersebut adalah metode statistik. Metode statistik menguraikan distribusi spasial nilai keabuan intensitas citra. Penguraian yang dimaksud adalah dengan menghitung secara lokal fitur di setiap titik dalam citra (Jahne, 2005). 
Ada beberapa aplikasi dalam pengenalan pola yang memerlukan citra masukan dengan ukuran tertentu agar proses lebih mudah dilakukan. Perubahan ukuran dalam penentuan citra masukan mengadopsi teknik interpolasi. Kualitas citra hasil interpolasi tentu tidak sama dengan kualitas citra asli. Penelitian ini membahas tentang pengaruh interpolasi terhadap tekstur suatu citra khususnya fitur statistic.

(Han, 2013) telah melakukan riset terhadap empat buah metode interpolasi yaitu nearest neighbor interpolation, bilinear interpolation, bicubic interpolation dan cubic B-Spline interpolation. Keempat metode ini dievaluasi berdasarkan nilai SNR. Nilai SNR yang semakin besar menunjukan bahwa kualitas citra hasil interpolasi semakin baik. Dari keempat, metode bicubic interpolation mempunyai nilai SNR yang lebih baik. (Olivier, 2012) melakukan pengembangan bilinear interpolation menjadi suatu metode interpolasi baru yang bernama nearest neighbor value interpolation. Metode ini mengadaptasikan bilinear interpolation dengan nearest neighbor interpolation. Metode ini bertujuan untuk mengurangi underestimation atau overestimation dari tekstur citra.

\section{METODE PENELITIAN}

Penelitian dilakukan dengan 10 buah citra uji grayscale berukuran $256 \times 256$. Setiap citra diinterpolasi dengan faktor perbesaran sama dengan 2. Metode interpolasi yang dilakukan dterhadap setiap citra. Ada 4 metode interpolasi yang digunakan yaitu NNI, Bilinear Interpolation, Bicubic Interpolation dan NNV. Kemudian, citra hasil interpolasi dibandingkan dengan citra asli berukuran $512 \times 512$. Perbandingan ini dapat diukur dengan SSIM untuk mengetahui kualitas citra hasil interpolasi. Selain perbandingan kualitas citra, perbandingan tekstur citra juga dilakukan.

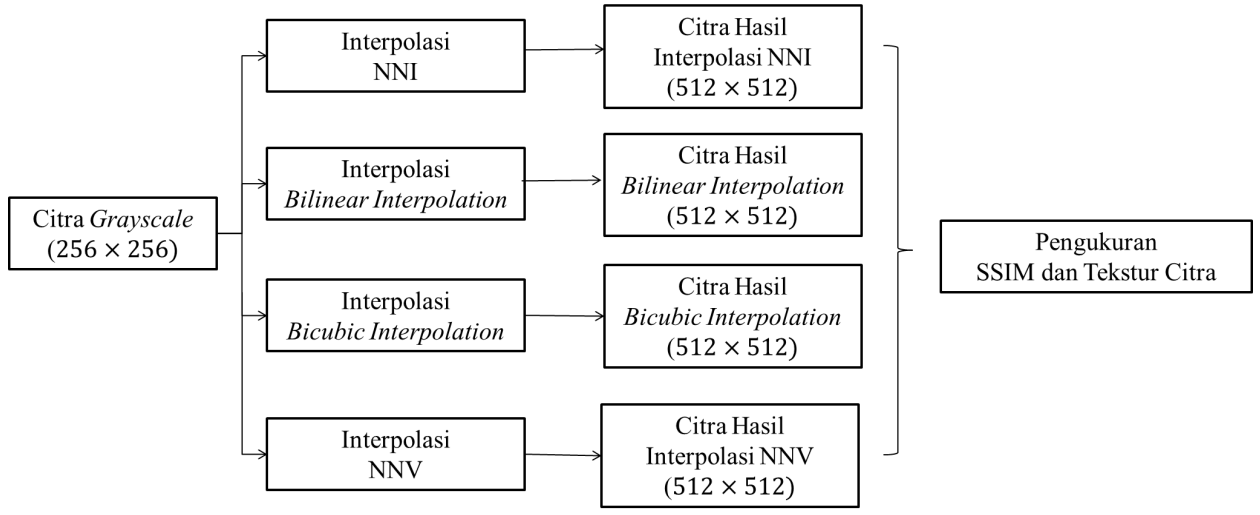

Gambar 1 Diagram Pengukuran SSIM dan Tekstur Citra

\section{Interpolasi}

Resampling adalah sebuah metode pencitraan untuk meningkatkan (atau mengurangi) jumlah piksel dalam citra digital (Gonzales, 2002). Interpolasi adalah suatu proses menentukan nilai yang baru di suatu posisi yang terletak diantara beberapa sample. Penentuan nilai baru tersebut dilakukan dengan suatu fungsi tertentu. Interpolasi citra bekerja dalam dua arah dan mencoba untuk mencapai pendekatan yang terbaik dari sebuah piksel yang warna dan intensitasnya didasarkan pada nilai-nilai di sekitar piksel. Beberapa contoh interpolasi adalah Nearest Neighbor Interpolation (NNI), bilinear interpolation, bicubic interpolation (Fadnavis, 2014) dan nearest neighbor value interpolation (Olivier, 2012). 


\section{Nearest Neighbor Interpolation (NNI)}

Nearest Neighbor Interpolation (NNI) adalah metode paling sederhana dan pada dasarnya membuat piksel lebih besar. Jika citra diperbesar 200\% maka satu piksel akan diperbesar $2 \times 2$ luas dari 4 piksel dengan warna yang sama seperti aslinya piksel.

Dalam metode ini setiap piksel hasil interpolasi didapat dari nilai tetangga terdekat pada citra masukan. Kernel interpolasi dari metode NNI adalah

$h(x)=\left\{\begin{array}{lll}0 ; & |x| & >0 \\ 1 ; & |x| & <0\end{array}\right.$

Frekuensi response dari kernel NNI adalah

$H(\omega)=\operatorname{sinc}(\omega / 2)$

Walaupun metode ini sangat sederhana, tetapi kualitas yang dihasilkan kurang baik.

\section{Bilinear Interpolation}

Bilinear interpolation menentukan nilai piksel baru berdasarkan rata-rata (dengan memberi bobot) dari 4 piksel dari ukuran $2 \times 2$ piksel tetangga terdekat dalam gambar asli. Metode ini ratarata memiliki efek anti-aliasing dan karena itu relatif mulus pada bagian tepinya. Kernel bilinear interpolasi adalah

$u(x)=\left\{\begin{array}{c}0 ; \quad|x|>1 \\ 1-|x| ; \quad|x|<1\end{array}\right.$

$\mathrm{X}$ adalah jarak diantara 2 titik yang diinterpolasi.

\section{Bicubic Interpolation}

Bicubic interpolation adalah interpolasi dengan metode yang lebih canggih dan hasilnya lebih halus pada bagian tepi-tepinya daripada bilinear interpolation. Bicubic menggunakan $4 \times 4$ piksel tetangga untuk mengambil informasi. Bicubic menghasilkan gambar yang terasa lebih tajam dari dua metode sebelumnya, dan mungkin merupakan kombinasi ideal waktu proses dan output yang berkualitas. Ini adalah metode yang paling sering digunakan oleh perangkat lunak editing. Kernel interpolasi dari bicubic interpolation adalah

$$
W(x)=\left\{\begin{array}{c}
(a+2)|x|^{2}-(a+3)|x|^{2}+1 \text { untuk }|x| \leq 1 \\
a|x|^{2}-5 a|x|^{2}+8 a|x|-4 a \text { untuk } 1<|x|<2 \\
0 \text { untuk lainnya }
\end{array}\right.
$$

\section{Nearest Neighbor Value Interpolation (NNV)}

Nearest Neighbor Value Interpolation (NNV) adalah suatu pengembangan interpolasi yang menerapkan algoritma bilinear interpolation. Nilai hasil interpolasi didapat dengan mencari selisih nilai piksel hasil bilinear interpolation dengan nilai piksel tetangganya. Tujuan dari mendapatkan nilai selisih adalah untuk meminimalkan underestimation atau overestimation dari bagian citra dari tekstur citra setelah proses interpolasi (Olivier, 2012).

Langkah-langkah untuk melakukan NNVI adalah melakukan kalkulasi dengan empat tetangga piksel baru, mendapatkan nilai perbedaan minimum antara empat piksel tetangga dengan nilai bilinear.

Langkah pertama: menghitung nilai bilinear dan membandingkan nilai piksel asli dengan hasil bilinear. Dimisalkan terdapat piksel awal A, K, P dan G, dengan piksel baru hasil bilinear adalah B. Perbedaan antara nilai piksel A, K, P dan G dengan piksel B akan dihitung.

$$
\begin{aligned}
& |A-B|=V_{1} \\
& |K-B|=V_{2} \\
& |P-B|-V_{3} \\
& |G-B|=V_{4}
\end{aligned}
$$


Langkah kedua: mendapatkan nilai minimum dari keempat perbedaan $V_{1}, V_{2}, \mathbb{V}_{3}$ dan $V_{1}$.

Jika sudah didapatkan nilai minimum diantara keempat $\mathrm{V}$ tersebut maka nilai piksel baru dapat ditentukan. Penentuan nilai piksel baru dapat dilakukan dengan mengurangi nilai hasil bilinear dengan nilai $\mathrm{V}$ minimum tersebut.

\section{Tekstur Citra}

Tekstur suatu citra didefinisikan sebagai hubungan mutual antara nilai intensitas beberapa piksel yang bertetangga. Metode sederhana untuk mendapatkan tekstur adalah dengan berdasarkan pada histogram (Gonzales, 2002) (Susanto, 2012). Fitur pertama yang dapat dihitung secara statistis adalah rerata intensitas. Komponen fitur ini dihitung dengan persamaan:.

$\mu=\sum_{i=0}^{L-1} i \cdot p(i)$

Dalam hal ini, i adalah aras keabuan pada citra $f$ dan $p(i)$ menyatakan probabilitas kemunculan i dan L menyatakan nilai aras keabuan tertinggi. Rumus di atas akan menghasilkan rerata kecerahan objek.

Fitur kedua berupa deviasi standar.

$$
\sigma=\sqrt{\sum_{i=1}^{L-1}(i-\mu)^{2} p(i)}
$$

Fitur skewness merupakan ukuran ketidaksimetrisan terhadap rerata intensitas.

skewness $=\frac{\sum_{i=1}^{L-1}(i-\mu)^{3} p(i)}{(L-1)^{2}}$

Energi adalah ukuran yang menyatakan distribusi intensitas piksel teradap jangkauan aras keabuan.

$$
\text { energy }=\sum_{i=0}^{L-1}[p(i)]^{2}
$$

Entropi mengindikasikan kompleksitas citra. Semakin tinggi nilai entropi, semakin kompleks citra tersebut. Perlu diketahui, entropi dan energi cenderung berkebalikan. Entropi juga merepresentasikan jumlah informasi yang terkandung di dalam sebaran data.

entropy $=-\sum_{i=0}^{L-1} p(i) \log _{2}(p(i))$

Properti kehalusan (smoothness) biasa disertakan untuk mengukur tingkat kehalusan intensitas pada citra

$$
R=1-\frac{1}{1+\sigma^{2}}
$$

\section{Structural Similarity Index Metrics (SSIM)}

SSIM dikenal sebagai kualitas metric yang digunakan untuk mengukur kemiripan diantara 2 buah citra dan dipercaya berkorelasi dengan kualitas persepsi Human Visual System (HVS) (Wang, 2004). Model SSIM dibuat dengan memperhatikan 3 buah faktor yaitu loss of correlation, luminance distortion dan contrast distortion. 


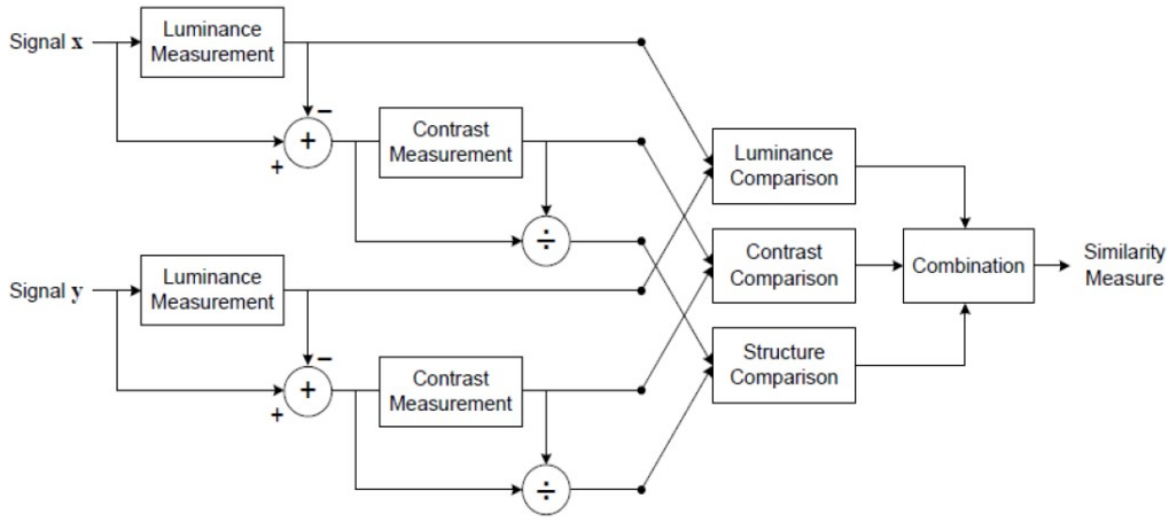

Gambar 2 Diagram Sistem Pengukuran SSIM (Soong, 2012)

Persamaan SSIM dapat dilihat pada (9)

$\operatorname{sSIM}(f, g)=l(f, g) c(f, g) s(f, g)$

Dengan

$$
\left\{\begin{array}{l}
l(f, g)=\frac{2 \mu_{f} \mu_{g}+c_{1}}{\mu f^{2}+\mu_{g}+C_{1}} \\
c(f, g)=\frac{2 \sigma_{f} \sigma_{g}+C_{z}}{\sigma_{f}{ }^{3}+\sigma_{g}{ }^{2}+C_{2}} \\
s(f, g)=\frac{2 \sigma_{f q}+C_{s}}{\sigma_{f} \sigma_{g}+c_{g}}
\end{array}\right.
$$

$l(f, g)$ adalah perbandingan luminansi yang mengukur kemiripan nilai luminansi rerata 2 citra $\left(\mu_{f}\right.$ dan $\left.\mu_{g}\right)$. Nilai maksimal dari nilai $l(f, g)$ sama dengan 1 . Nilai maksimal akan tercapai bila $\mu_{f}=\mu_{g}$

$c(f, g)$ adalah perbandingan nilai kontras yang mengukur kemiripan nilai standar deviation 2 citra yaitu $\sigma_{f}$ dan $\sigma_{g}$. Nilai maksimal dari nilai $\mathrm{c}(f, g)$ sama dengan 1. Nilai maksimal akan tercapai bila $\sigma_{f}=\sigma_{g}$

$s(f, g)$ adalah perbandingan struktur yang mengukur koefisien korelasi diantara 2 citra $(f, g)$. $\sigma_{f g}$ adalah nilai kovarian antara $f$ dan $g$.

Jangkauan nilai SSIM adalah 0 sampai dengan 1. Nilai "0" menunjukkan kedua citra yang dibandingkan tidak berkorelasi sedangkan nilai " 1 " menunjukkan kedua citra yang dibandingkan sama persis $f=g$.

$C_{1}, C_{2}$ dan $C_{3}$ adalah suatu konstanta agar penyebut tidak sama dengan nol.

\section{HASIL DAN PEMBAHASAN}

Terdapat 10 buah citra berskala keabuan dengan ukuran masing-masing $512 \times 512$. Kesepuluh citra uji dapat dilihat pada Gambar 3. Kesepuluh citra tersebut dihitung nilai tekstur citranya sebagai nilai tekstur dari citra asli. Nilai tekstur yang dihitung adalah rerata, standar deviasi, skewness, energi, entropi dan kehalusan. Interpolasi dilakukan terhadap 10 buah citra berskala keabuan dengan faktor interpolasi 2. Empat buah teknik interpolasi diteliti. Hasil citra interpolasi dengan faktor interpolasi sama dengan 2 dapat dilihat pada Gambar 4. 


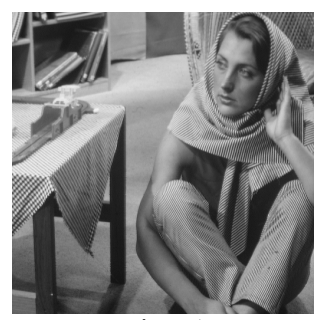

Citra 1

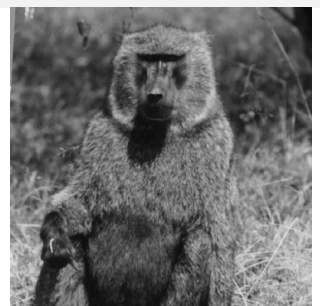

Citra 5

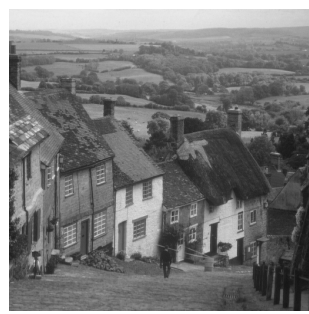

Citra 2

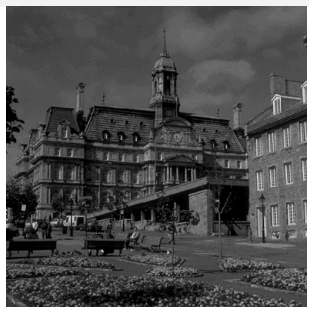

Citra 6

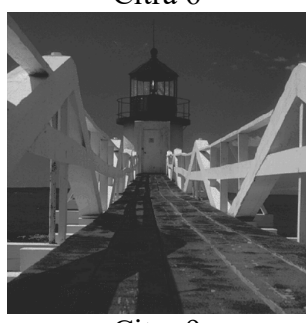

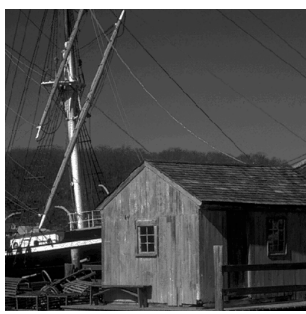

Citra 3

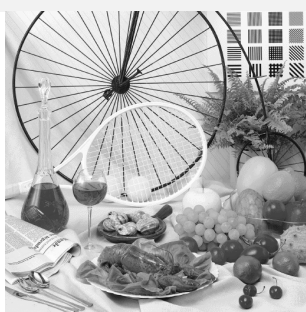

Citra 7

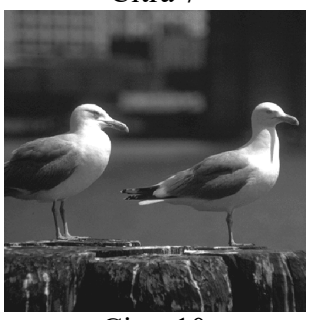

Citra 10

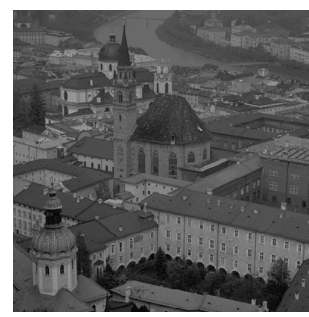

Citra 4

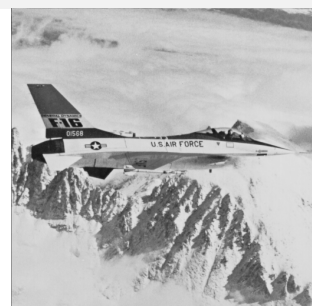

Citra 8

Gambar 3. Citra Asli Berskalakeabuan 512×512 (Lanjutan)

Pengaruh Interpolasi terhadap rerata citra dapat dilihat pada Gambar 5. Nilai rerata antara citra asli dengan citra hasil interpolasi berbeda-beda. Nilai perbedaan rerata dinyatakan dalam persentase. Perbedaan rerata yang ditunjukkan tidak sampai 1\%. Rata-rata perbedaan dari 10 citra yang diuji yaitu metode NNI berbeda $0,03 \%$, metode Bilinear Interpolation $0,23 \%$, metode Bicubic Interpolation 0,03\% dan metode NNV 0,49\%. Perbedaan citra hasil NNI memiliki nilai yang terkecil diantara metode lainnya. Perbedaan rerata terbesar ditunjukkan oleh citra hasil metode NNV. Dalam hal ini dapat dikatakan metode NNI paling tidak banyak merubah rerata citra. Rerata citra tahan terhadap proses interpolasi faktor 2.
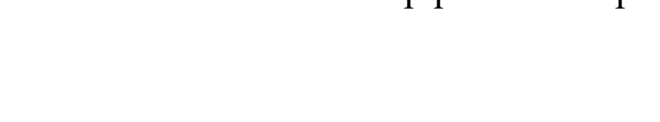

Citra 1 Hasil NNI

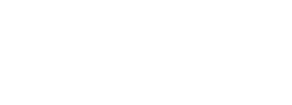

Citra 1 Hasil Bilinear Interpolation

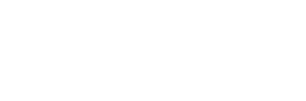

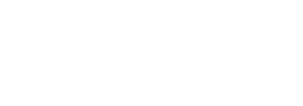

Citra 1 Hasil Bicubic Interpolation

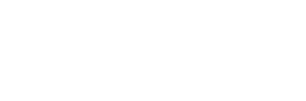

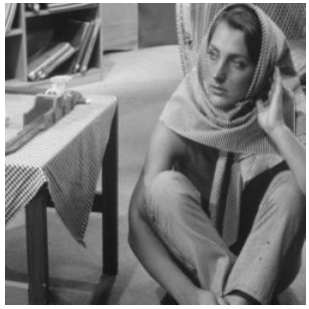

Citra 1 Hasil NNV

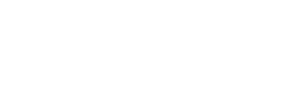

Citra 2 Hasil Bilinear Interpolation
Citra 2 Hasil Bicubic Interpolation
Citra 2 Hasil NNV 

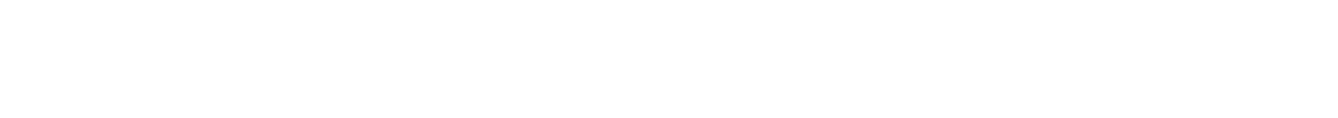

Citra 3 Hasil NNI

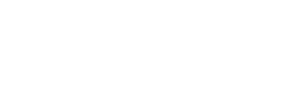

Citra 3 Hasil Bilinear Interpolation

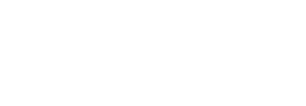

Citra 3 Hasil Bicubic Interpolation

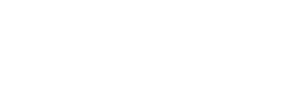

Citra 4 Hasil Bicubic Interpolation

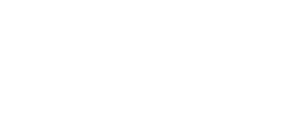

Citra 4 Hasil Bilinear Interpolation

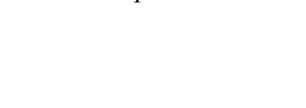

Citra 3 Hasil NNV

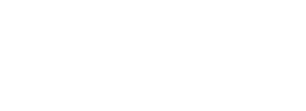

Citra 5 Hasil NNI

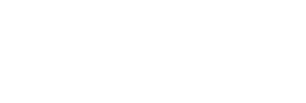

Citra 6 Hasil NNI

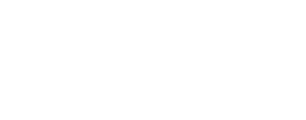

Citra 5 Hasil Bicubic Interpolation Interpolation

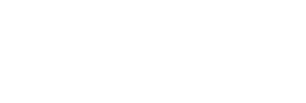

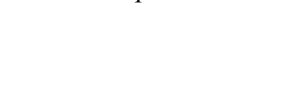

Citra 6 Hasil Bicubic Interpolation

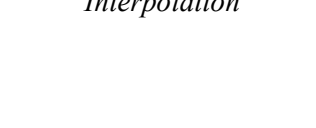

Citra 4 Hasil NNV

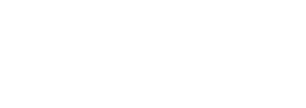

Citra 5 Hasil NNV

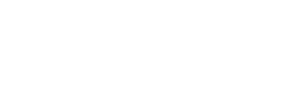

Citra 7 Hasil NNI

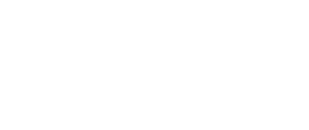

Citra 7 Hasil Bilinear Interpolation

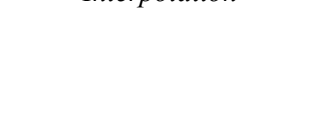

Citra 7 Hasil Bicubic Interpolation

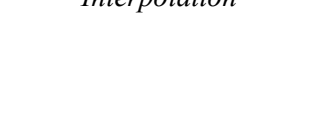

Citra 6 Hasil NNV

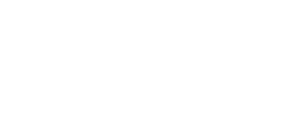

Citra 8 Hasil NNI

Citra 8 Hasil Bilinear Interpolation
Citra 8 Hasil Bicubic Interpolation
Citra 7 Hasil NNV

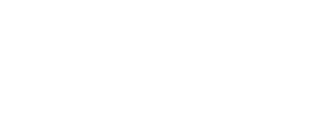



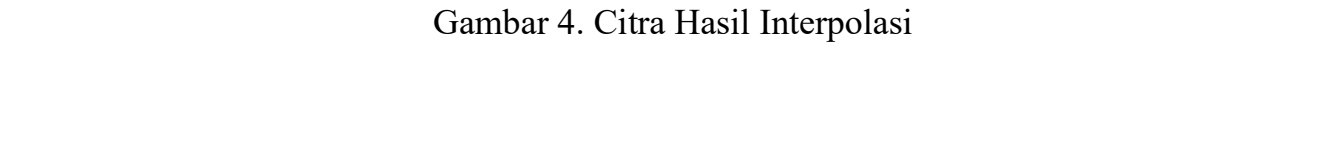

Citra 9 Hasil NNI

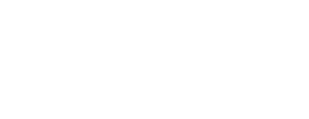

Citra 9 Hasil Bilinear Interpolation

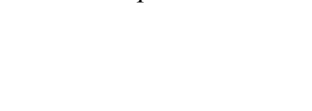

Citra 9 Hasil Bicubic Interpolation

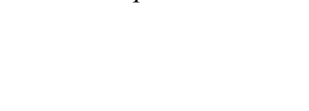

Citra 9 Hasil NNV

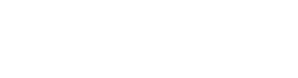

Citra 10 Hasil NNI

Citra 10 Hasil Bilinear Interpolation

Citra 10 Hasil Bicubic Interpolation

Citra 10 Hasil NNV

Gambar 4. Citra Hasil Interpolasi (Lanjutan)

Pengaruh Interpolasi terhadap deviasi standar citra dapat dilihat pada Gambar 6. Nilai deviasi standar antara citra asli dengan citra hasil interpolasi berbeda-beda. Nilai perbedaan deviasi standar dinyatakan dalam persentase. Perbedaan deviasi standar yang ditunjukkan hampir mencapai 10\%. Rata-rata perbedaan nilai standar deviasi dari kesepuluh citra yang diuji yaitu metode NNI berbeda 2,33\%, metode Bilinear Interpolation 5,05\%, metode Bicubic Interpolation 3,10\% dan metode NNV 4,11\%. Perbedaan nilai standar deviasi citra hasil NNI memiliki nilai yang terkecil diantara metode lainnya. Perbedaan nilai standar deviasi terbesar ditunjukkan oleh citra hasil metode bilinear interpolation. Dalam hal ini dapat dikatakan metode NNI tidak merubah fitur standar deviasi citra dibanding metode interpolasi yang lain. Fitur standar deviasi citra ini tidak tahan terhadap metode interpolasi.

Perbandingan Nilai Rerata Citra Hasil Interpolasi dengan Citra Asli

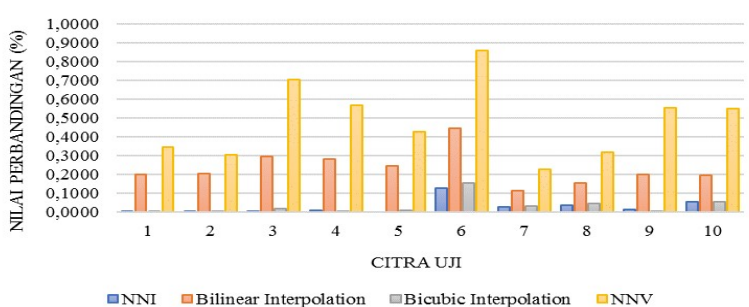


Gambar 5. Perbandingan Nilai Rerata Citra Hasil Interpolasi dengan Citra Asli

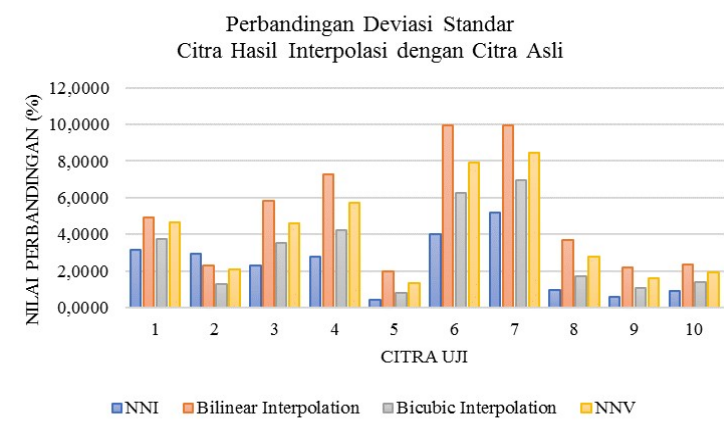

Gambar 6. Perbandingan Nilai Deviasi Standar Citra Hasil Interpolasi dengan Citra Asli

Pengaruh Interpolasi terhadap skewness citra dapat dilihat pada Gambar 7. Nilai skewness antara citra asli dengan citra hasil interpolasi berbeda-beda. Nilai perbedaan skewness dinyatakan dalam persentase. Perbedaan skewness yang ditunjukkan sangat besar bahkan melebihi $100 \%$ dan hampir mencapai $800 \%$. Perbedaan ini terlihat pada citra uji 6 . Hal ini disebabkan citra uji 6 mempunyai frekuensi distribusi piksel yang cukup tinggi diantara yang lainnya. Rata-rata perbedaan nilai skewness dari kesepuluh citra yang diuji yaitu metode NNI berbeda 65,75\%, metode Bilinear Interpolation 107,24\%, metode Bicubic Interpolation 87,15\% dan metode NNV 93,91\%. Perbedaan nilai skewness citra hasil NNI memiliki nilai yang terkecil diantara metode lainnya. Perbedaan nilai skewness terbesar ditunjukkan oleh citra hasil metode bilinear interpolation. Dalam hal ini dapat dikatakan metode NNI paling tidak banyak merubah fitur skewness citra.

Perbandingan Nilai Skewness Citra Hasil Interpolasi dengan Citra Asli

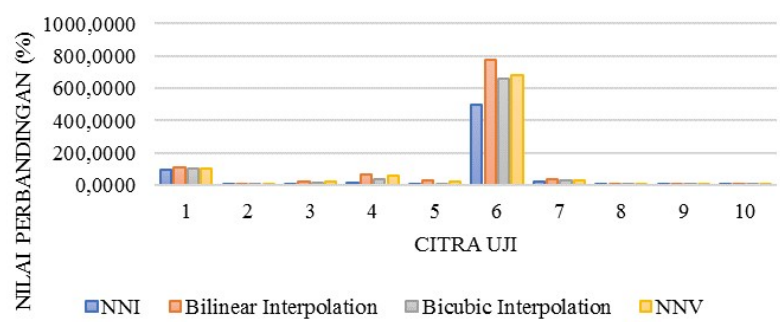

Gambar 7. Perbandingan Nilai Skewness Citra Hasil Interpolasi dengan Citra Asli

Pengaruh Interpolasi terhadap energi citra dapat dilihat pada Gambar 8. Nilai energi antara citra asli dengan citra hasil interpolasi berbeda-beda. Nilai perbedaan energi dinyatakan dalam persentase. Perbedaan energi yang ditunjukkan cukup besar hampir mencapai 90\%. Rata-rata perbedaan nilai energi dari kesepuluh citra yang diuji yaitu metode NNI berbeda 40,93\%, metode Bilinear Interpolation 40,45\%, metode Bicubic Interpolation 40,86\% dan metode NNV 40,11\%. Perbedaan nilai energi citra hasil NNV memiliki nilai yang terkecil diantara metode lainnya. Perbedaan nilai energi terbesar ditunjukkan oleh citra hasil metode NNI. Berbeda dari fitur citra sebelumnya, metode NNI mengubah energi, distribusi intensitas piksel, paling besar diantara metode lainnya. Pengaruh Interpolasi terhadap entropi citra dapat dilihat pada Gambar 9. Nilai entropi antara citra asli dengan citra hasil interpolasi berbeda-beda. Nilai perbedaan entropi dinyatakan dalam persentase. Perbedaan entropi yang ditunjukkan cukup besar hampir mencapai $80 \%$. Rata-rata perbedaan nilai entropi dari kesepuluh citra yang diuji yaitu metode NNI berbeda 20,02\%, metode Bilinear Interpolation 19,50\%, metode Bicubic Interpolation 19,92\% dan metode NNV 19,67\%. Perbedaan nilai entropi citra hasil Bilinear Interpolation memiliki nilai yang terkecil 
diantara metode lainnya. Perbedaan nilai entropi terbesar ditunjukkan oleh citra hasil metode NNI. Sama seperti halnya energi, metode NNI paling mempengaruh fitur entropi, tingkat kompleksitas, pada citra.

Pengaruh Interpolasi terhadap kehalusan citra dapat dilihat pada Gambar 10. Nilai kehalusan antara citra asli dengan citra hasil interpolasi berbeda-beda. Nilai perbedaan kehalusan dinyatakan dalam persentase. Perbedaan kehalusan yang ditunjukkan cukup besar hampir mencapai $80 \%$. Rata-rata perbedaan nilai kehalusan dari kesepuluh citra yang diuji yaitu metode NNI berbeda 4,07\%, metode Bilinear Interpolation 9,42\%, metode Bicubic Interpolation 5,84\% dan metode NNV 7,77\%.

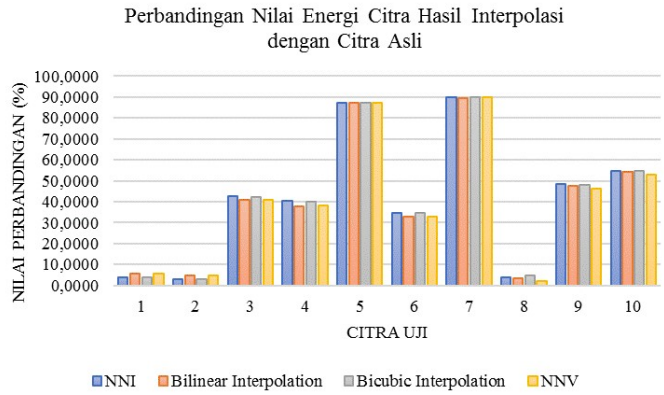

Gambar 8. Perbandingan Nilai Energi Citra Hasil Interpolasi dengan Citra Asli

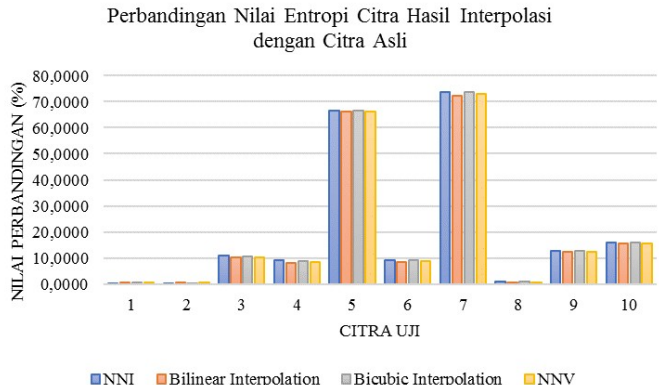

Gambar 9. Perbandingan Nilai Entropi Citra Hasil Interpolasi dengan Citra Asli

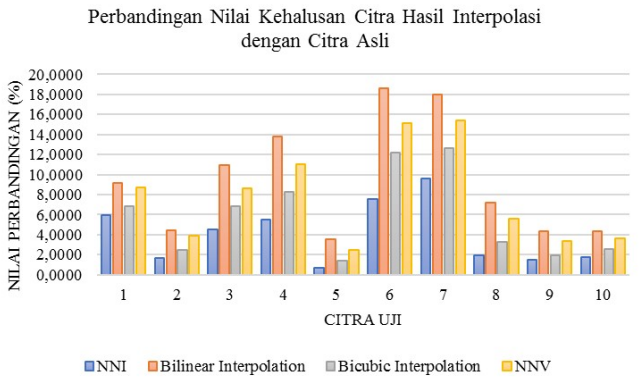

Gambar 10. Perbandingan Nilai Kehalusan Citra Hasil Interpolasi dengan Citra Asli

Setelah pengukuran tekstur citra hasil interpolasi dengan citra asli, pengukuran kemiripan terhadap kedua citra dilakukan. Pengukuran tersebut menggunakan indeks SSIM. Pengukuran indeks SSIM dapat dilihat pada Gambar 11. Citra hasil interpolasi dengan metode NNV mempunyai nilai SSIM yang lebih kecil bila dibandingkan nilai SSIM dengan metode lainnya. Nilai SSIM citra hasil interpolasi dengan metode Bilinear Interpolation mempunyai indeks SSIM lebih baik bila dibandingkan nilai SSIM citra hasil interpolasi dengan metode NNV. 
Untuk beberapa citra, nilai SSIM citra hasil interpolasi Bilinear Interpolation lebih baik dari nilai citra hasil interpolasi NNI. Hal ini terlihat pada citra 8, citra 9 dan citra 10. Namun, nilai SSIM citra hasil interpolasi Bilinear Interpolation tidak lebih baik dari citra hasil interpolasi Bicubic Interpolation. Nilai SSIM citra hasil interpolasi dengan metode NNI lebih baik dari pada nilai SSIM citra hasil interpolasi dengan metode Bilinear Interpolation pada citra 1, citra 2, citra 3, citra 4, citra 5 dan citra 6. Namun, nilai SSIM citra hasil interpolasi NNI tidak lebih baik dari nilai SSIM citra hasil interpolasi Bicubic Interpolation pada 9 citra uji. Nilai SSIM citra hasil interpolasi dengan metode Bicubic Interpolation lebih baik bila dibandingkan nilai SSIM citra hasil interpolasi dengan metode lainnya. Namun pada citra 1, nilai SSIM citra hasil interpolasi dengan metode Bicubic Interpolation tidak lebih baik daripada nilai SSIM citra hasil interpolasi dengan metode NNI.

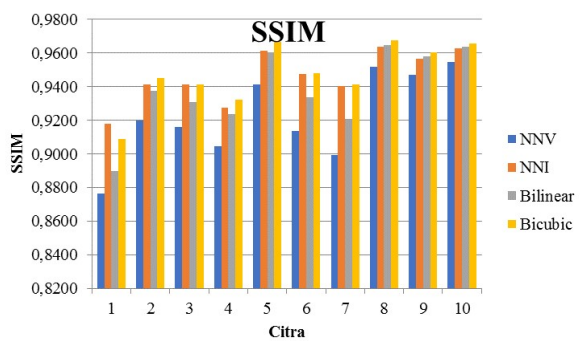

Gambar 11. Pengukuran Indeks SSIM Citra Hasil Interpolasi dengan Citra Asli

Perbandingan keempat metode interpolasi ini dapat dilihat pada Tabel 1.

Tabel 1. Perbandingan Metode Interpolasi berdasar Subjective Feeling, Kualitas Citra dan Komputasi

\begin{tabular}{cccc}
\hline Jenis Interpolasi & Subjective Feeling & Kualitas Citra & Komputasi \\
\hline NNV & Tidak terlalu blur & Dapat dipertahankan & Berat \\
\hline NNI & Mosaic phenomenon & Cukup Baik & Ringan \\
\hline Bilinear Interpolation & Blur & Baik & Cukup Berat \\
\hline Bicubic Interpolation & Lebih tajam & Sangat Baik & Berat \\
\hline
\end{tabular}

\section{KESIMPULAN}

Interpolasi mengubah tekstur citra. Setiap interpolasi menghasilkan citra dengan tekstur yang berbeda antara satu teknik dengan teknik lainnya. Penelitian ini membandingkan 4 buah metode interpolasi dan 6 buah fitur tekstur citra dengan 10 buah citra yang diuji. Dari keenam tekstur citra yang diteliti, fitur skewness adalah fitur yang mengalami perubahan yang sangat besar hampir mencapai $800 \%$, diikuti dengan fitur energi yang mengalami perubahan maksimum hampir mencapai $90 \%$, entropi $75 \%$, kehalusan $18 \%$, deviasi standar $10 \%$ dan rerata $0,9 \%$.

Pengukuran SSIM citra hasil interpolasi dengan citra asli mencapai nilai paling baik dengan metode Bicubic Interpolation 90\% citra uji menunjukkannya. Metode NNV tidak mendukung nilai SSIM yang baik karena nilai SSIM hasil interpolasi NNV lebih rendah dibanding nilai SSIM lainnya.

\section{REFERENSI}

Avcibas, I., Sankur, B., \& Sayood, K. (2002). Statistical Evaluation of Image Quality Measures. Journal of Electronic Imaging, 11 (2), 206-223.

Al-Najjar, Y.A.Y., \& Soong, D.D.C. (2012). Comparison of Image Assesment: PSNR, HVS, SSIM, UIQI. International Journal of Sciencetific \& Engineering Research, 3 (8), 11-15. 
Cadik, M., \& Slavik, P. (2004). Evaluation of Two Principal Approaches to Objective Image Quality Assesment. 8th International Conference on Information Visualitsation, IEEE Computer Science Society Press, 513-551.

Chang, A. S. (1992). Image Information Systems: Where Do We Go From Here? IEEE Trans. On Knowledge and Data Engineering, 5(5), 431-442.

Farrel, J.E. (1999). Image Quality Evaluation in Colour Imaging: Vision and Technology (Mac Donald, L. W. And Luo, M.R. ed, pp. 285-313): John Wiley.

Gonzales, R.C., \& Woods, R.E. (2002). Digital Image Processing 2nd edition. Prenctice Hall.

Han, D. (2013). Comparison of Commonly Used Image Interpolation Methods. Proceedings of the 2nd International Conference on Computer Science and Electronics Engineering (ICCSEE 2013), 1556-1559.

Hastuti, I. M. H. (2009). Content Based Image Retrieval Berdasarkan Fitur Bentuk Menggunakan Metode Gradient Vector Flow Snake. Seminar Nasional Informatika 2009 (semnasIF 2009) UPN "Veteran" Yogyakarta, 23 Mei 2009, ISSN: 1979-2328, A-140-A145.

Jahne, B. (2005). Digital Image Processing. Germany: Springer-Verlag Berlin.

Khare, C., \& Nagwanshi, K. (Februari 2012). Image Restoration Techniques with Non Linear Filter. International Journal of Advanced Science and Technology, 39.

Kreis, R. (2004). Issues of Spectral Quality in Clinical H-Magnetic Resonance Spectroscopy and a Gallery of Artifacts. NMR in Biomedicine, 17 (6), 361-381.

Kodituwakku, S. S. (2011). Analysis and Comparison of Texture Features for Content Based Image Retrieval. International Journal of Latest Trends in Computing, 2(1), 108-113.

Levine, M. (1985). Vision in Man and Machine. McGraw-Hill.

Nguyen, T.B., \& Ziou, D. (2000) Contextual and Non-contextual Performance Evaluation of Edge Detectors. Pattern Recognition Letters, 21 (9), 805-816.

Olivier, R., \& Hanqiang, C. (2012). Nearest Neighbor Value Interpolation. IJACSA (International Journal of Advanced Computer Science and Applications vol. 3, No. 4, 1-6.

Smulders, A.M.W, W. M. (2000). Content-Based Image Retrieval at The End of The Early Years. IEEE Transaction on Pattern Analysis and Machine Intelligence, 22(12), 13491380 .

Susanto A., \& Kadir, A. (2012). Pengolahan Citra : Teori dan Aplikasi. Penerbit Andi.

Wang, Z., Bovik, A.C., Sheikh, H.R., \& Simmoncelli, E.P. (2004). Image Quality Assessment: From Error Visibility to Structural Similarity. IEEE Transactions on Image Processing, Image Processing and Pattern Recognition, 8(11), 221-230. 